\title{
HEAT CONSUMPTION AND QUALITY OF MILK PASTEURIZATION
}

\author{
Viera KAŽIMÍROVÁ \\ Slovak University of Agriculture in Nitra, Slovakia
}

This paper deals with milk processing with emphasis on pasteurization. The heat treatment of milk is important in terms of product quality and health safety. The goal of this paper is determination of heat consumption, inactivation effect and Pasteur criterion, by which pasteurization effectiveness is evaluated. The methodical part contains calculations, which were used for estimation of results and description of a pasteurization station used for milk processing. Results obtained in usual working time confirmed that necessary heating and cooling performance were achieved for guarantee of high-quality milk production. Real specific heat consumption was $51.69 \mathrm{~kJ} / \mathrm{kg}$. It was achieved by use of regeneration sections in the pasteurizer. These sections allow for a repeated use of $82 \%$ of heat used for heating of raw milk in pasteurization.

Keywords: pasteurization, heat consumption, inactivation effect

The average consumption of milk in Slovakia is 50 litres per person a year, which is less than the European average. The total consumption of milk and dairy products is 157 kilograms per person a year (Šajbidorová, 2012). Slovak dairy products are currently of high quality and they can compete with foreign products.

The thermal treatment of milk is important in terms of high quality of the final product and in terms of energy demands of dairy production. Pasteurization is a thermal process in which temperatures lower than $100^{\circ} \mathrm{C}$ affect the milk and $90-99 \%$ of vegetative forms of microorganisms are eradicated (Kažimírová, 2005).

Pasteur criterion is used for quality evaluation of pasteurization. Its value is calculated as a ratio of necessary time of pasteurization at the specified temperature and real time of milk flow through effective zones of the pasteurizer (Groda, 1996).

The energy demand of food production is compared to its nutrition energy efficiency. It is a ratio of the food's energy value and energy consumption in its production. Its inverted value describes how many times energy consumption is higher than the usable energy value of food (Šepitka a Šepitková, 1988).

\section{Material and methods}

The goal of this paper is the analysis of thermal treatment of milk intended for the production of human nutrition. It is focused on determination of heat energy for milk pasteurization, consisting of consumption of heat for achieving the pasteurization temperature and refrigeration duty for cooling of milk after pasteurization, inactivation effect and Pasteur criterion by which pasteurization effectiveness is evaluated.

Measurements were performed in the pasteurizer PPM 2010 AN. The performance of the pasteurizer is 20,000 litres per hour. Dismountable plate pasteurizer is composed of four sections, frame and partition panels. A centrifuge, homogenizer and holding tube, surge tank with floater, milk pump, hot water tank, hot water pump, water-steam mixer, connecting pipe and armature are components of the pasteurizing system.

Plates Sigma with a surface area of $0.5 \mathrm{~m}^{2}$ that have the greatest effect on thermodynamic properties as a basic module are used in the pasteurizer. The thickness of the plate is $0.6-0.8 \mathrm{~mm}$. Plates are made of titanium. The efficient surface of plates is burnished, which, combined with turbulent flow, is manifested by minimizing of incrustations and dirt generation.

This pasteurizer is countercurrent; hot water (up to $110^{\circ} \mathrm{C}$ ) is used for milk heating in the pasteurization section. Cooling water is used for milk cooling in the cooling section.

\section{Heat consumption by pasteurization}

Measurements of milk temperatures in the plate pasteurizer are necessary for determination of heat consumption. Milk and water temperatures are measured in points made accessible by pasteurizer design. These points are shown in Fig. 1. Temperatures were measured by a data acquisition system Almemo 5590-2 and immersion temperature sensor FTA126 with a measurement range of $-200-900{ }^{\circ} \mathrm{C}$. Other necessary values are calculated. Heat consumption and refrigeration duty of pasteurization are determined by these values.

Heat consumption for milk heating from temperature $t_{1}$ to pasteurization temperature tp is calculated using the equation:

$$
\dot{Q}=\dot{m}_{1} \cdot c_{1}\left(t_{p}-t_{1}\right), W
$$

where:

$\dot{m}_{1} \quad$ - milk flow, $\mathrm{kg} / \mathrm{s}$

$c_{1} \quad$ - specific heat of milk, $\mathrm{J} /\left(\mathrm{kg} .{ }^{\circ} \mathrm{C}\right)$

$t_{1} \quad$ - temperature of raw milk, ${ }^{\circ} \mathrm{C}$

$t_{p} \quad$ - pasteurization temperature of milk, ${ }^{\circ} \mathrm{C}$

Specific heat consumption for heating of milk is:

$$
q=\frac{\dot{Q}}{\dot{m}_{1}}=c_{1}\left(t_{p}-t_{1}\right), \mathrm{J} / \mathrm{kg}
$$




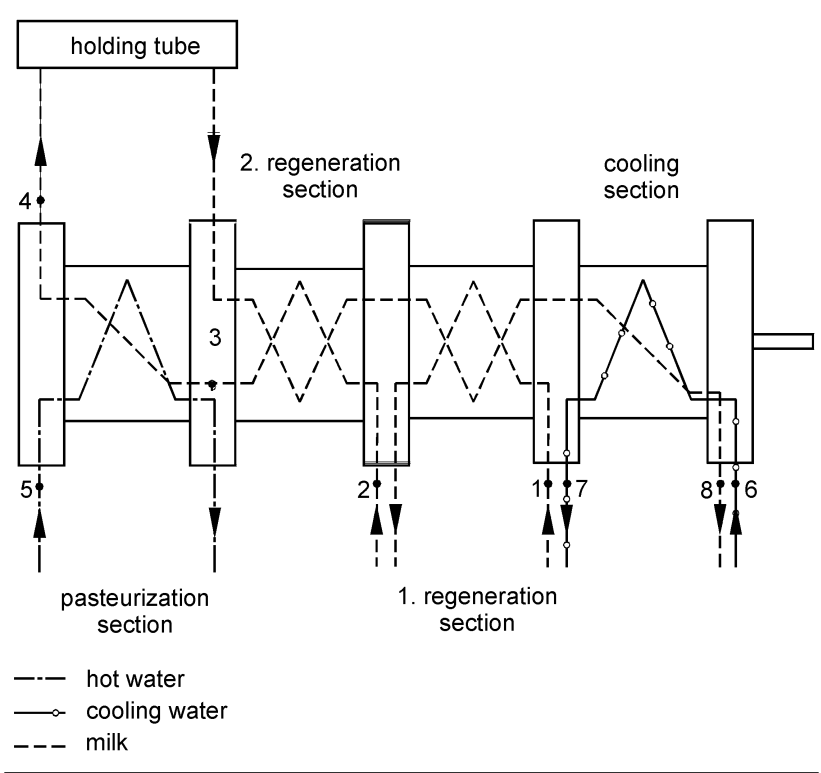

Figure 1

Schematic diagram of plate pasteurizer with measurement points

1 - initial temperature of raw milk $t_{1} ; 2$ - temperature of milk between the first and second regeneration section $t_{2} ; 3$ - temperature of milk at the input of pasteurization section $t_{3} ; 4$ - pasteurization temperature $t_{4}=t_{p^{\prime}} 5$ - input temperature of hot water $t_{5} ; 6$ - input temperature of cooling water $t_{6} ; 7$ - output temperature of cooling water $t_{7} ; 8$ - temperature of milk at the output of cooling section $t_{8}$

Refrigeration duty in the cooling section of the pasteurizer for milk cooling from temperature $t_{6}$ to output temperature $t_{7}$ is calculated using the equation:

$$
\dot{Q}_{c h}=\dot{m}_{1} \cdot c_{1}\left(t_{6}-t_{7}\right), \mathrm{W}
$$

Specific refrigeration duty for milk cooling after pasteurization:

$$
q_{c h}=\frac{\dot{Q}_{c h}}{\dot{m}_{1}}=c_{1}\left(t_{6}-t_{7}\right), \mathrm{J} / \mathrm{kg}
$$

The efficiency of heat recuperation in regeneration sections is calculated using the equation:

$$
\eta=\frac{t_{3}-t_{1}}{t_{p}-t_{1}}
$$

Real heat consumption for milk heating is:

$$
\dot{Q}_{r}=(1-\eta) \cdot \dot{Q}, \mathrm{~W}
$$

Real specific heat consumption is:

$$
q_{r}=\frac{\dot{Q}_{r}}{\dot{m}_{1}}, \mathrm{~J} / \mathrm{kg}
$$

Milk temperature at the input of the cooling section $t_{9}$ is calculated by calorimetric equation, using measured individual temperatures and refrigeration duty in the cooling section:

$$
\dot{Q}_{c h}=\dot{m}_{1} \cdot c_{1}\left(t_{9}-t_{8}\right) \Rightarrow t_{9}=\frac{\dot{Q}_{c h}}{\dot{m}_{1} \cdot c_{1}}+t_{8},{ }^{\circ} \mathrm{C}
$$

Output temperature of hot water $t_{10}$ is also calculated by calorimetric equation:

$$
\dot{Q}_{p}=\dot{m}_{1} \cdot c_{1}\left(t_{4}-t_{3}\right)=\dot{m}_{2} \cdot c_{2}\left(t_{5}-t_{10}\right) \Rightarrow t_{10}=t_{5}-\frac{\dot{Q}_{p}}{\dot{m}_{2} \cdot c_{2}}
$$
where:

$\dot{Q}_{p} \quad$ - heat consumption in the pasteurization section, W

\section{Inactivation effect determination}

The pasteurization process of milk is efficient if the milk retains pasteurization temperature for the duration needed to inactivate pathogenic microbiota in the milk. To evaluate the pasteurization efficiency, Pasteur criterion (PA), according to which the pasteurization process is effective if $\mathrm{PA} \geq 1$, can be used.

Table 1 Temperature values in plate pasteurizer

\begin{tabular}{|l||c|c|c|c|c|c|c|c|}
\hline \multirow{2}{*}{$\begin{array}{l}\text { Measurement } \\
\text { number }\end{array}$} & \multicolumn{9}{|c|}{ Temperature in measurement point in ${ }^{\circ} \mathbf{C}$} \\
\hline \hline 1 & $\mathbf{1}$ & $\mathbf{2}$ & $\mathbf{3}$ & $\mathbf{4}$ & $\mathbf{5}$ & $\mathbf{6}$ & $\mathbf{7}$ & $\mathbf{8}$ \\
\hline 2 & 5.7 & 48.2 & 60.1 & 72.4 & 85.3 & 1.5 & 6.7 & 4.6 \\
\hline 3 & 5.1 & 48.0 & 60.0 & 72.2 & 84.6 & 1.6 & 6.4 & 4.8 \\
\hline 4 & 5.4 & 48.0 & 61.0 & 72.1 & 84.8 & 2.1 & 6.8 & 5.3 \\
\hline 5 & 5.1 & 48.6 & 60.4 & 72.6 & 84.6 & 1.8 & 7.0 & 5.2 \\
\hline 6 & 6.0 & 48.1 & 60.1 & 72.2 & 84.4 & 1.5 & 6.2 & 5.0 \\
\hline 7 & 5.6 & 47.9 & 60.1 & 72.0 & 84.6 & 2.0 & 6.0 & 5.1 \\
\hline 8 & 5.2 & 48.3 & 60.6 & 71.8 & 85.0 & 2.6 & 6.0 & 4.9 \\
\hline 9 & 5.4 & 48.1 & 60.4 & 72.2 & 84.7 & 1.6 & 6.4 & 5.6 \\
\hline 10 & 5.4 & 47.9 & 60.2 & 72.5 & 84.7 & 1.9 & 6.7 & 5.3 \\
\hline & 5.3 & 48.6 & 60.1 & 72.0 & 85.0 & 1.5 & 6.4 & 5.1 \\
\hline SD & 5.42 & 48.17 & 60.30 & 72.20 & 84.77 & 1.81 & 6.46 & 5.09 \\
\hline SE mean & 0.28 & 0.26 & 0.31 & 0.25 & 0.26 & 0.35 & 0.35 & 0.28 \\
\hline
\end{tabular}


Pasteur criterion for the tube holder is calculated using the equation (Groda, 1996):

$$
P A_{h}=\frac{T_{h}}{Z_{h}}
$$

where:

$T_{h} \quad$ - time of milk flow through the holding tube, $s$

$Z_{h} \quad$ - time needed for inactivation effect to take place, $s$

\section{Evaluation of results}

Measured values of temperatures were processed by a descriptive statistics procedure. Mean $(\bar{X})$, standard deviation (SD) and standard error of mean (SE mean) were calculated.

Average temperatures were used for calculation of heat consumption and refrigeration duty in pasteurization and Pasteur criterion using equation (10).

\section{Results and discussion}

Measured values of temperatures in individual measurement points are shown in Tab. 1. Ten measurements were done during continuous operation and average values were calculated using these results. Means were used for following calculations.

Average values of individual temperatures, standard deviation and the standard error of mean were statistically determined. These values are shown in Tab. 1. Results of measurements show that all values of individual temperatures are clustered in intervals with small margins. This is a consequence of a well-functioning control device and points out that at the time of measurements, fluctuations of energy supply did not occur, which means that the steam for production of hot water had constant pressure.

\section{Heat consumption calculation}

Theoretical heat consumption for heating of milk from the input temperature of raw milk to pasteurization temperature, calculated using Equation (1), is 1,642.52 kW. Milk flow through the pasteurizer was $5.72 \mathrm{~kg} / \mathrm{s}$; the specific heat of milk at $40{ }^{\circ} \mathrm{C}$ is $4,300 \mathrm{~J} /\left(\mathrm{kg} .{ }^{\circ} \mathrm{C}\right)$.

Theoretical specific heat consumption calculated using Equation (2) is $287.15 \mathrm{~kJ} / \mathrm{kg}$.

Refrigeration duty for cooling of milk after pasteurization is $214.67 \mathrm{~kW}$. The flow of cooling water was $11.1 \mathrm{~kg} / \mathrm{s}$; the specific heat of cooling water at $4{ }^{\circ} \mathrm{C}$ is $4,186 \mathrm{~J} /\left(\mathrm{kg} .{ }^{\circ} \mathrm{C}\right)$. Specific refrigeration duty calculated using Equation (4) is $37.5 \mathrm{~kJ} / \mathrm{kg}$.

The efficiency of recuperation calculated using Equation (5) is 0.82 . Real heat consumption for milk heating calculated using equation (7) is $295.65 \mathrm{~kW}$, and real specific heat consumption calculated using equation (8) is 51.69 $\mathrm{kJ} / \mathrm{kg}$. The difference between theoretical and actual heat consumption is caused by heat savings that were reached in regenerative heat recovery sections.

Milk temperature at the input of the cooling section $t_{9}$ calculated using equation (8) is $13.62^{\circ} \mathrm{C}$.

The output temperature of hot water $t_{10}$ is calculated using equation (9). Its value is $78.47^{\circ} \mathrm{C}$. Hot water flow was $11.1 \mathrm{~kg} / \mathrm{s}$.

\section{Inactivation effect determination}

The pasteurization section, tubular holding tube and regeneration section (in milk backflow) partake in inactivation of pathogenic microorganisms by thermal treatment.

Pasteur criterion is calculated using the values of holding time and pasteurization temperature of milk. The holding time of milk through the holding tube was 25 seconds. The holding time needed in pasteurization at a temperature of $72{ }^{\circ} \mathrm{C}$ is 11 seconds. This time was determined from the graph in Fig. 2 (Prekopp, 1966).

This graph was constructed using the values calculated by Dahlberg's equation, in which constants characteristic of tuberculosis germs were used. The minimum temperature and the time of pasteurization are not sufficient to achieve the necessary pasteurization effect; therefore, it is required to increase these values. Modified values are: temperature $71.1^{\circ} \mathrm{C}$, time $15 \mathrm{~s}$.

According to the Regulation (EC) No 853/2004, heat treatment at $72{ }^{\circ} \mathrm{C}$ should last $15 \mathrm{~s}$. Values obtained by measurements are in accordance with this regulation.

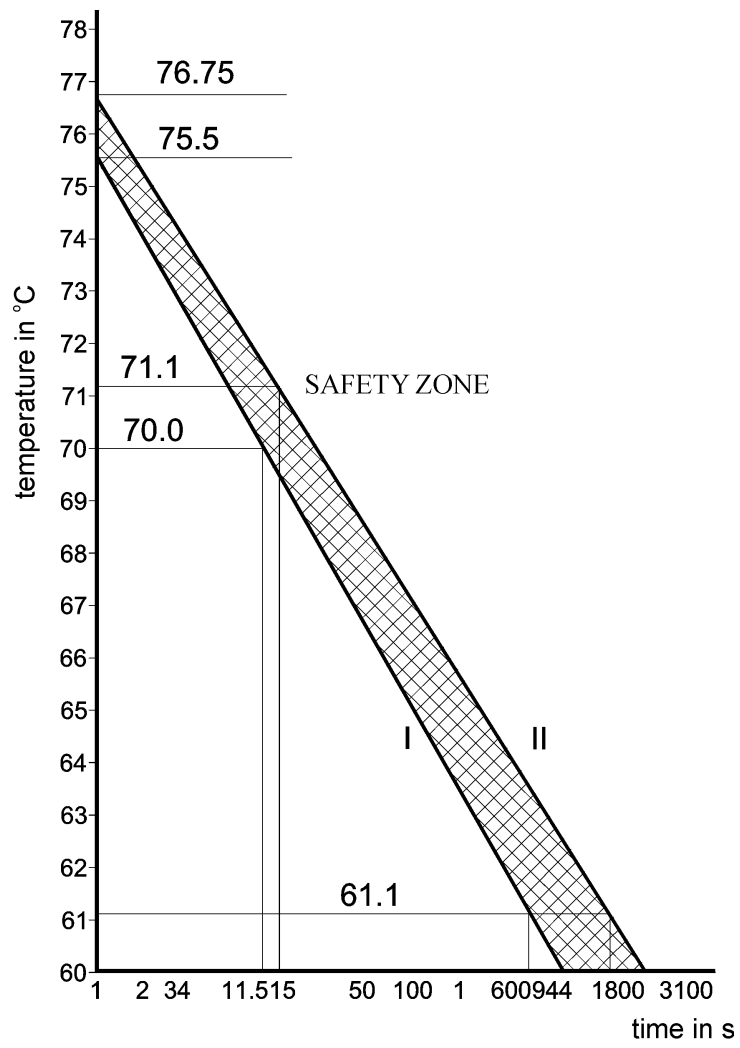

\begin{tabular}{ll}
\hline Figure 2 & $\begin{array}{l}\text { Diagram of pasteurization temperature and time } \\
\text { required to eradicate the microorganisms in milk } \\
\text { Source: Prekopp, } 1966\end{array}$
\end{tabular}

Pasteur criterion for the tube holder calculated using Equation (10) is 2.27. This value meets the condition of pasteurization effect efficiency $P A \geq 1$.

\section{Conclusion}

The research paper deals with the heat treatment of milk, which is an important part of the production of high-quality 
and healthy milk for human nutrition. Pasteurization is the main heat process in dairy industry.

Results of the work show that the operation of the pasteurizer, together with machine control and automation achieves necessary heating and cooling capacity for production of high-quality milk and dairy products. Theoretical specific heat consumption for pasteurization of milk is $287.15 \mathrm{~kJ} / \mathrm{kg}$, but real specific heat consumption was $51.69 \mathrm{~kJ} / \mathrm{kg}$. It was achieved by using regeneration sections in the pasteurizer. These sections allow reusing $82 \%$ of heat used in pasteurization.

Pasteur criterion for the tube holder is 2.27 . The

\section{References}

evaluation of pasteurization effect also pointed out a satisfactory performance of the pasteurizer.

GRODA, B. 1996. Kvalita biotechnických soustav získávání, ošetřování a finalizace mléka : habilitačná práca. Brno : MZLU. 211 s.
KAŽIMÍROVÁ, V. 2005. Technika na konzerváciu, pasterizáciou a sterilizáciou. In RUŽBARSKÝ, J. a kol. Potravinárska technika. Prešov : FVT, s. 337-341. ISBN 80-8073-410-0.

PREKOPP, I. 1966. Mechanizácia v mliekarstve. Bratislava : SNTL. $516 \mathrm{~s}$. REGULATION (EC) No 853/2004 of the European Parliament and of the Council of 29 April 2004 laying down specific hygiene rules for food of animal origin.

ŠAJBIDOROVÁ, V. 2012. Mlieko [online]. Bratislava : VÚEPP. ISSN 1338-4848. Dostupné na: http://www.vuepp.sk/dokumenty/komodity/2012/mlieko.pdf

ŠEPITKA, A. - ŠEPITKOVÁ, J. 1988. Energetika v technológiách potravinárskeho priemyslu. Bratislava : Príroda. $173 \mathrm{~s}$.

Company materials of TENEZ a. s. (joint stock company), Chotebor, Czech Republic.

\section{Contact address:}

Ing. Viera Kažimírová, PhD., Department of Production Engineering, Faculty of Engineering, Slovak University of Agriculture in Nitra, Tr. Andreja Hlinku 2, 94976 Nitra, Slovak Republic, $\mathbf{m}$ +421 37641 4403, e-mail: viera.kazimirova@ uniag.sk 